\title{
The Influence of E-Service Quality on Online Repurchase Intentions with Variables of Satisfaction as Mediation in Cafe and Resto in The City Of Padang in the Time of he Covid-19 Pandemic
}

\author{
Maygita Karlina ${ }^{1}$, Ma'ruf ${ }^{2}$ \\ ${ }^{1}$ Magister of Management, Faculty of Economic, Andalas University \\ Padang, West Sumatra, Indonesia \\ ${ }^{2}$ Doctor, Faculty of Economic, Andalas University \\ Padang, West Sumatra, Indonesia
}

\begin{abstract}
:
The existence of the government's Large-Scale Social Restrictions (PSBB) policy during the Covid-19 pandemic encouraged every industrial sector to focus on online transactions. One of the industries in question is the food industry, represented by cafes and restaurants that are starting to pay attention to the concept of e-service quality to support the increase in online repurchase intentions in an effort to maintain business continuity. This study aims to determine the effect of E-Service Quality on Online Repurchase Intentions with the satisfaction variable as a mediation at cafes and restaurants during the Covid-19 pandemic. The causal quantitative research method, with this research design using a cross sectional study. The sample used is 170 customers who make online purchases at cafes \& restaurants in the city of Padang. The data collection process uses a questionnaire, with the distribution presented in the form of an electronic questionnaire which is one of the google docs applications that can be accessed online via the internet by customers of online cafes and restaurants in Padang city, West Sumatra, Indonesia. In this study, there are three types of variables used, namely the first independent variable, namely e-service quality, the second is the mediating variable, namely customer satisfaction, and the third dependent variable is online repurchase intentions. Data analysis in this study used Partial Least Square (PLS). The results showed that E-Service Quality has a positive and significant effect on customer satisfaction and Online Repurchase Intention. Customer satisfaction also has a positive and significant effect on Online Repurchase Intention. The results of the mediation test show that satisfaction plays a role as a mediation between E-Service Quality and Online Repurchase Intention.
\end{abstract}

Keywords: E-Service Quality, Customer Satisfaction, Online Repurchase Intentions.

\section{Introduction}

Indonesia is facing the Covid-19 pandemic and it has been running for 8 months starting from February 2020 since positive cases were found. The widespread spread of Covid-19 creates a serious threat to the global economy (Burhanuddin \& Abdi, 2020). The Covid-19 pandemic has an impact on various sectors. The food and beverage industry sector is the most affected compared to other industries. The results of a survey conducted in 17 cities in Indonesia including Jakarta, Bogor, Depok, Tangerang, Bekasi, Bandung, Semarang, Yogyakarta, Surabaya, Medan, Batam and Bali showed that 13 cities experienced a significant decrease in daily income due to Covid-19 (Merdeka, 2020).

The food and beverage industry sector in question is restaurants and cafes that have begun to close due to a shift in customer consumption patterns due to the Covid-19 pandemic. Customers initially buy conventionally, namely eating and drinking on the spot, but because there are government policies that prohibit crowds, the way to keep attracting customers is to optimize services with an online buying system through the concept of take away or delivery service.

This condition explains that the cafe \& restaurant industry in order to survive during the Covid-19 pandemic needs to have a strategy to improve the quality of electronic services to increase customer satisfaction, thus increasing online repurchase intention. In a customer-oriented business, service 
quality contributes to the company's success. If not prioritized, customers will move.

Repurchase intention is the desire to repurchase a product or service for a second or more time for the same product or service (Dharmmesta, 2014), (Ibzan, Balarabe, \& Balarabe, 2016), (Saodin, Suharyono, Arifin, \& Sunarti, 2019). Then online repurchase intention is defined as the desire to repurchase online. Customer retention reflects the success of online shopping and a way of gaining a competitive advantage which increases profitability due to lower customer sensitivity to price changes and a stronger likelihood of referring new customers. However, compared to offline, increasing online repurchase intention is more difficult because of the challenges associated with online shopping (Chou \& Hsu, 2016).

There are several factors that need to be considered in order to develop a competitive advantage in online business, namely improving the quality of services offered online or what is known as eservice quality (Rita, Oliveira, \& Farisa, 2019). The quality of electronic services that pampers its users will encourage customers to reopen the company which will foster a sense of loyal customers to the company (Hasman, Ginting, \& Rini, 2019).

E-Service Quality is quality service electronically in effective and efficient transaction activities (Hasman et al., 2019). E-service quality can also be described as an electronic-based service that has reliability, assurance, and efficiency in making purchases and services, as well as delivery of a product (Zeithaml, Parasuraman, \& Malhotra, 2002). One of the most widely used e-service quality models is the eservqual model from Zeithaml et al., which is more comprehensive and integrative because it is relevant to meet the need to evaluate e-service quality in general. E-Servqual model from Zeithaml et al. has seven dimensions, namely: 1) Efficiency, ease of searching for information on a product online. 2) Reliability, the technical functionality of the site operating as intended. 3) Guarantee, covering what is offered as promised. 4) Privacy refers to the level of security of customer data. 5) Responsiveness, refers to the accuracy of solutions to customer problems, such as product returns or warranty availability. 6) Compensation, including refunds, shipping costs, and product handling fees. 7) Contact person, the customer needs to contact the seller directly via the telephone network (Zeithaml et al., 2002).
Good e-service quality affects customer satisfaction which will have a positive impact on online repurchase intention of the same seller (Saodin et al., 2019), (Rita et al., 2019), (Hasman et al., 2019), (Lestari \& Ellyawati, 2019), (Santoso \& Aprianingsih, 2017). Phuong \& Tran argue that business actors who provide high e-service quality affect customer satisfaction and will encourage customers to make repurchases (Phuong \& Tran, 2018). Apart from service quality, another thing that encourages online repurchase intention is customer satisfaction. According to Lestari \& Ellyawati, overall customer satisfaction is related to the intensity of reusing services from the same provider (Lestari \& Ellyawati, 2019). Rita et al. also emphasized that when customers are satisfied with an online store, the customer's repurchase intention to shop online will increase (Rita et al., 2019). Therefore, the importance of e-service quality and customer satisfaction on online repurchase intention at cafes \& restaurants, so this research will test eservice quality to show the level of service quality and its relationship with customer satisfaction which can affect online repurchase intention.

This research was conducted on cafes \& restaurants in the city of Padang, West Sumatra, which were also affected by the Covid-19 pandemic. A number of cafes \& restaurants in the city of Padang have experienced a decline in turnover related to the outbreak of the Covid-19 pandemic (Abdi, 2020). This has made several cafe \& restaurant places in the city of Padang change their service to e-service with the concept of take away or delivery. Several cafes and restaurants in Padang City use their own websites and social media accounts belonging to cafes and restaurants such as WhatsApp or Instagram to market and serve customers. Therefore, this study aims to determine the effect of e-service quality and online repurchase intention on customer satisfaction and at cafes and restaurants in Padang City during the Covid-19 pandemic.

\section{Literature Review and Hypothesis Development}

\subsection{The Influence of E-Service Quality on Customer Satisfaction}

Quality of service in electronics provides services via an internet. Zeithaml et al. stated that e-service quality is the quality perceived by customers for purchases or services electronically (Zeithaml et al., 2002). E-service quality is more important than conventional because customers do not make faceto-face contact with the seller. This online customer is often faced with uncertainty, anonymity, lack of 
control, and the potential for taking opportunities to be deceived (Alwafi \& Magnadi, 2016). This means that electronic service quality is important to provide quality fulfillment that exceeds customer needs, so as to provide a level of customer satisfaction. This shows that e-service quality can increase customer satisfaction. Previous research has confirmed that there is a positive and significant influence between e-service quality on customer satisfaction (Saodin et al., 2019), (Rita et al., 2019), (Hasman et al., 2019), (Santika \& Pramudana, 2018). Research from Lestari \& Ellyawati shows that e-service quality has a positive and significant effect on customer satisfaction (Lestari \& Ellyawati, 2019). Based on the description above, the following hypothesis is formulated:

H1: E-Service Quality has a positive and significant effect on customer satisfaction

\subsection{The Influence of E-Service Quality on Online Repurchase Intention}

E-Service Quality is an important instrument in developing competitive advantage in online business (Rita et al., 2019). The quality of electronic services that pampers its users will encourage customers to reopen the company which will foster a sense of loyal customers to the company (Hasman et al., 2019). The results of previous research prove that $E$ Service Quality has a positive and significant effect on Online Repurchase Intention (Saodin et al., 2019), (Hasman et al., 2019), (Santoso \& Aprianingsih, 2017). Research from Lestari \& Ellyawati shows that ease of use, website design, responsiveness, and personalization have a positive and significant effect on repurchase intention (Lestari \& Ellyawati, 2019). Based on the description above, the following hypothesis is formulated:

H2: E-Service Quality has a positive and significant effect on Online Repurchase Intention

\subsection{The Influence of Customer Satisfaction and Online Repurchase Intention}

Customer satisfaction can be used as a measure of repurchase interest. Dissatisfaction arises when the products offered by producers do not match customer expectations (Santoso \& Aprianingsih, 2017). Satisfied online customers will likely shop again and recommend to others, while dissatisfied customers will leave their online retailer with or without complaints. This means that satisfaction is directly related to customer positive behavioral intentions (Rita et al., 2019). Previous literature has confirmed that there is a positive and significant effect of customer satisfaction on Online Repurchase Intention (Hasman et al., 2019; Phuong \& Tran, 2018; Rita et al., 2019; Santoso \& Aprianingsih, 2017; Saodin et al., 2019). Based on the description above, the following hypothesis is formulated:

H3: Customer Satisfaction has a positive and significant effect on Online Repurchase Intention

\subsection{The Influence of E-Service Quality on Online Repurchase Intention with Customer Satisfaction as Mediation}

The role of customer satisfaction in e-service quality is very important because it will have an impact on online repurchase intention. Satisfaction is a consequence of customer experience during the buying process, and plays an important role in influencing future customer behavior, such as repurchase intention. E-service quality also has a positive influence, both directly and indirectly, on satisfaction and also online repurchase intention (Rita et al., 2019). According to Saodin et al. (2019) satisfaction is not directly related to repurchase. However, customer satisfaction influences repurchase behavior from the viewpoint of psychological research, where satisfaction drives intention, whereas intention drives behavior. Therefore, repurchase is an indicator of satisfaction as well as an effect of the purchase. The results of research by Hasman et al. proved that E-Service Quality has a positive and significant effect on repurchase intention through electronic satisfaction (Hasman et al., 2019). Meanwhile, Research from Lestari \& Ellyawati shows that satisfaction mediates in partial mediation the effect of ease of use, website design, responsiveness, and personalization on repurchase intention (Lestari \& Ellyawati, 2019). Meanwhile, satisfaction is proven to be full mediation of the effect of security assurance on repurchase intention. Based on the description above, the following hypothesis is formulated:

H4: Customer satisfaction acts as a mediating variable between E-Service Quality and Online Repurchase Intention

\section{Research Methods}

The research approach used is quantitative because it tests the theory with existing facts through statistical tests. This type of research investigation is included in the causal research type, which is testing the causal relationship between two or more variables, through testing the hypotheses that have been made (Silalahi, 2018). In addition, the design of this study used a cross sectional study. The cross- 
sectional method means that the study design was carried out in a cross-sectional, instantaneous, at the same time and measured only once without any follow-up action on the variables in question (Sekaran \& Bougie, 2016).

The research approach used is quantitative because it tests the theory with existing facts through statistical tests. This type of research investigation is included in the causal research type, which is testing the causal relationship between two or more variables, through testing the hypotheses that have been made (Sugiyono, 2017). In addition, the design of this study used a cross sectional study. The cross sectional method means that the study design was carried out in a cross-sectional, instantaneous, at the same time and measured only once without any follow-up action on the variables in question (Sekaran \& Bougie, 2016).

Basically, the number of population in this study cannot be known with certainty, so the sample was selected using proportion sampling. Hair et al. recommend that the sample size should be 100 or greater (Hair et al., 2014). As a general rule, the minimum sample size is at least 5 or 10 times the number of question items to be analyzed. In this study, there are 17 statement items, so the sample size required is at least $17 \times 10=170$ samples.

The operational definition of each variable uses different literature. E-service quality uses dimensional measurements based on research by Zeithaml et al., which consists of efficiency, reliability, fulfillment, privacy, responsiveness, compensation, and contact (Zeithaml et al., 2002). The next variable is satisfaction which is described based on research from Rita et al. (Rita et al., 2019) and online purchase intention using measurements based on research from Saodin et al. (Saodin et al., 2019).

Data collection using a questionnaire. To get samples, use several social networking sites as well as personal websites for cafes and restaurants in the city of Padang. The questionnaire is distributed in the form of an electronic questionnaire which is one of the google docs applications that can be accessed online via the internet by customers of online cafes and restaurants in the city of Padang, which are then analyzed using the Structural Equation Model (SEM) Partial Least Square (PLS).

\section{Result and Discussion \\ 4.1 Research Result \\ 4.1.1 Respondent Identity}

The results of descriptive analysis regarding the profile of the research respondents described based on age are shown in Table 1 below.

Table 1: Respondent Identity

\begin{tabular}{|c|c|c|c|}
\hline No & Information & Frequency & Percentage \\
\hline \multicolumn{4}{|c|}{ Age } \\
\hline 1 & 18-25 tahun & 36 & 21.2 \\
\hline 2 & 26-30 tahun & 74 & 43.5 \\
\hline 3 & 31-35 tahun & 32 & 18.8 \\
\hline 4 & 36-40 tahun & 21 & 12.4 \\
\hline 5 & $>40$ tahun & 7 & 4.1 \\
\hline \multicolumn{4}{|c|}{ Level of Education } \\
\hline 1 & Senior High School & 32 & 18.8 \\
\hline 2 & Diploma & 10 & 5.9 \\
\hline 3 & Graduate degree (S1) & 88 & 51.8 \\
\hline 4 & Master's degree (S2) & 37 & 21.8 \\
\hline 5 & Doctor degree (S3) & 3 & 1.8 \\
\hline \multicolumn{4}{|c|}{ Current Work } \\
\hline 1 & Student / Student & 57 & 33.5 \\
\hline 2 & General employees & 49 & 28.8 \\
\hline 3 & $\begin{array}{c}\text { Civil servants / honorary } \\
\text { staff }\end{array}$ & 30 & 17.6 \\
\hline 4 & entrepreneur & 23 & 13.5 \\
\hline 5 & $\begin{array}{l}\text { employees of state-owned } \\
\text { enterprises }\end{array}$ & 11 & 6.5 \\
\hline \multicolumn{4}{|c|}{ Online Purchasing } \\
\hline 1 & $2-3$ times & 81 & 47.6 \\
\hline 2 & 4-5 times & 60 & 35.3 \\
\hline \multirow[t]{2}{*}{3} & $>5$ times & 29 & 17.1 \\
\hline & Amount & 170 & $100 \%$ \\
\hline
\end{tabular}

Source: processed data

\subsubsection{Hypothesis Test Using Structural Equation Model}

Hypothesis testing is done using bootstrapping on SmartPLS 3.0. The hypothesis is accepted or rejected can be seen with the probability value $(\mathrm{P}$ Values) and T-Statistics. The hypothesis will be accepted if the value of T-Statistics > T-Table (1.64) because it uses the one-tailed hypothesis and $\mathrm{P}$ values $<0.05$.

Table 2: Path Coefficient \& Hypothesis

\begin{tabular}{|l|c|c|c|c|}
\hline & Estimate & $\begin{array}{c}\text { T } \\
\text { Statistics }\end{array}$ & $\begin{array}{c}\text { P } \\
\text { Values }\end{array}$ & $\begin{array}{c}\text { Conclusi } \\
\text { on }\end{array}$ \\
\hline $\begin{array}{l}\text { E-Service Quality -> } \\
\text { Satisfaction }\end{array}$ & 0.643 & 11.658 & 0.000 & accepted \\
\hline $\begin{array}{l}\text { E-Service Quality -> } \\
\text { Online Repurchase } \\
\text { Intention }\end{array}$ & 0.245 & 2.511 & 0.012 & accepted \\
\hline $\begin{array}{l}\text { Satisfaction -> Online } \\
\text { Repurchase Intention }\end{array}$ & 0.568 & 5.847 & 0.000 & accepted \\
$\begin{array}{l}\text { E-Service Quality -> } \\
\text { Satisfaction -> Online } \\
\text { Repurchase Intention }\end{array}$ & 0.365 & 4.705 & 0.000 & accepted \\
\hline
\end{tabular}

Source: processed data

Table 2. is a test of the direct effect between exogenous and endogenous variables. Based on the table above, it can be concluded that the E-Service 
Quality variable has a positive and significant effect on satisfaction, because the T-Statistical value is 11.658> T-Table (1.64) and $P$ values are 0.000 $(<\mathrm{x} 0.05)$. The E-Service Quality variable has a positive and significant effect on Online Repurchase Intention, because the T-Statistics value is $2.511>\mathrm{T}$ Table (1.64) and P Values is $0.012(<x 0.05)$. The satisfaction variable has a positive and significant effect on Online Repurchase Intention, because the T-Statistic value is 5.847> T-Table (1.64) and the P value is $0.000(<0.05)$. In the test results the indirect effect of the E-Service Quality variable with Online Repurchase Intention mediated by satisfaction is significant. This is because the T-Statistics value is 4.705> T-Table (1.64) and $\mathrm{P}$ values $(0.000)<0.05$.

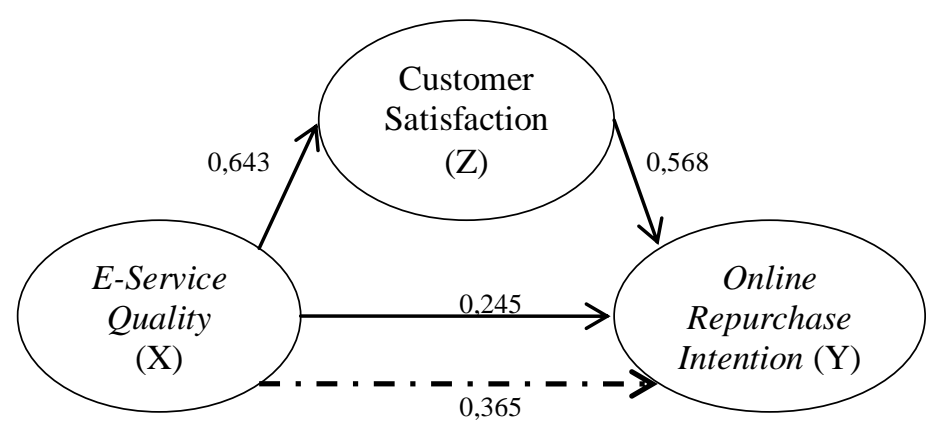

$\mathbf{-} \cdot \mathbf{-} \cdot \mathbf{-} \quad=$ Indirect Effect

Figure 1: The Results Of The Research

\subsection{Discussion}

\subsubsection{E-Service Quality Has A Positive And Significant Effect On Customer Satisfaction}

The analysis result shows that the effect of EService Quality on customer satisfaction is significant. As well as E-Service Quality, customer satisfaction will increase, and vice versa. This means that E-Service Quality is very important in increasing customer satisfaction. The relationship between E-Service Quality and customer satisfaction can be explained that the main factor determining customer satisfaction in an online business to consumer (B2C) environment is the customer's perception of the quality of goods or services according to their expectations (Rita et al., 2019). This shows that E-Service Quality can increase customer satisfaction. The results of this study support previous research which states that there is a positive and significant influence between E-Service Quality on customer satisfaction (Hasman et al., 2019; Rita et al., 2019; Santika \& Pramudana, 2018; Saodin et al., 2019).

The respondents in this study were mostly millennials. Millennial generation is not only known for its consumptive lifestyle, tends to be lazy, and has a hangout lifestyle, it is also known for its familiar lifestyle with information technology. The millennial generation is known as the information technology literate generation. Gadgets for the millennial generation are a necessity so that wherever they go, gadgets are never left behind. This is a correlation with the millennial lifestyle which is consumptive and tends to be lazy, so that sellers offer a variety of products online (Simanjuntak, 2020). Seeing this, business actors must provide the best service online in order to achieve customer satisfaction. Demands for satisfaction from the millennial generation because of a shift in value that makes the millennial market tend to choose or use a product. This is because the quality of service when serving the millennial generation even though it is not face to face is an important thing to consider for millennial generation consumers.

\subsubsection{E-Service Quality Has A Positive And Significant Effect On Online Repurchase Intention}

The analysis result shows that the effect of EService Quality on Online Repurchase Intention is significant. The better the E-Service Quality, the more Online Repurchase Intention will increase, and vice versa. This means that E-Service Quality is very important in increasing Online Repurchase Intention. The relationship between E-Service Quality and Online Repurchase Intention can be explained that to increase Online Repurchase Intention, business actors need to pay attention to the availability of by-phone services, ensure that they can maintain the security of customers' personal information, provide a sense of security in making transactions through websites or social media accounts, like WhatsApp or Instagram, and improve fulfillment of needs when making online purchases through the ideal website or application (Santoso \& Aprianingsih, 2017). This shows that E-Service Quality can improve Online Repurchase Intention. The results of this study support previous research which states that E-Service Quality has a positive and significant effect on Online Repurchase Intention (Hasman et al., 2019).

The improvement of E-Service Quality for the millennial generation who are very proficient in utilizing technology through social media such as Facebook, Twitter, Instagram, WhatsApp and others is the trigger for Online Repurchase Intention (Saodin et al., 2019). This means that the millennial generation will be interested in repurchasing online based on the level of E-Service Quality offered. In this case, the millennial genders expect the Padang 
City Cafe \& restaurant to provide by phone services if needed and most importantly that ordering via the website or social media accounts, such as WhatsApp or Instagram and the Padang City Cafe \& Restaurant is able to provide $100 \%$ refund services. if the order does not arrive.

\subsubsection{Customer Satisfaction Has A Positive And Significant Effect On Online Repurchase Intention}

The analysis results show that the effect of customer satisfaction on Online Repurchase Intention is significant. The higher the customer satisfaction, the more Online Repurchase Intention will increase, and vice versa. This means that customer satisfaction is very important in increasing Online Repurchase Intention. The relationship between satisfaction and Online Repurchase Intention can be explained that a satisfied online customer is likely to shop again and recommend it to others. Meanwhile, dissatisfied customers will leave cafes \& restaurants with or without complaints (Rita et al., 2019). The relationship between satisfaction and Online Repurchase Intention can be explained that a satisfied online customer is likely to shop again and recommend it to others. Meanwhile, dissatisfied customers will leave cafes \& restaurants with or without complaints (Rita et al., 2019). This shows that satisfaction can increase Online Repurchase Intention. The results of this study support previous research which states that there is a positive and significant influence between satisfaction with Online Repurchase Intention (Hasman et al., 2019; Phuong \& Tran, 2018; Rita et al., 2019; Santoso \& Aprianingsih, 2017; Saodin et al., 2019).

The results of this study indicate that satisfaction can increase Online Repurchase Intention because it is supported by the subjects in this study that most of the millennial generation. This generation really pays attention to reviews or appreciates feedback from online ordering whether the rating is high or low. if the seller has a high rating, then there is a tendency for this generation to intend to repurchase online.

\subsubsection{Customer Satisfaction Acts As A Mediating Variable Between E-Service Quality And Online Repurchase Intention}

The results of the analysis show that satisfaction is a mediation between E-Service Quality and Online Repurchase Intention. This means that E-Service Quality does not directly affect Online Repurchase Intention but it needs satisfaction first. In other words, good E-Service Quality will increase satisfaction, so that satisfied customers will increase Online Repurchase Intention. These findings also indicate that E-Service Quality and satisfaction have a direct influence on Online Repurchase Intention. Customers who get a good E-Service Quality will have high satisfaction. A high level of satisfaction will increase the intensity of Online Repurchase Intention. In line with the research of Rita et al., EService Quality satisfaction also has a positive influence, either directly or indirectly, on satisfaction and Online Repurchase Intention (Rita et al., 2019). According to Saodin et al. satisfaction is not directly related to repurchase (Saodin et al., 2019). However, customer satisfaction influences repurchase behavior from the viewpoint of psychological research, where satisfaction drives intention, whereas intention drives behavior. Therefore, repurchase is an indicator of satisfaction as well as an effect of the purchase. The results of this study support the findings of Hasman et al. that e-service quality has a positive and significant effect on repurchase intention through electronic satisfaction (Hasman et al., 2019).

Millennial generation is a generation that has high hopes for what they want. High expectations after the buying experience can increase sensitivity to a product or service, thus encouraging repeat purchases. Millennials who have high expectations are closely related to high concerns. E-service quality that cannot provide assurance, privacy and security can reduce the level of satisfaction and ultimately have an impact on reducing repeat purchases.

\section{Conclusion, Limitations, and Suggestions 5.1 Conclusion}

Based on the results in this study, it can be concluded that the effect of E-Service Quality on satisfaction is significant, which means that the better the E-Service Quality, the better the satisfaction, and vice versa. E-Service Quality is very important in increasing customer satisfaction at Cafe \& Restaurant in Padang City. The analysis result also shows that the influence of E-Service Quality on Online Repurchase Intention is significant, which shows that the better the EService Quality, the more Online Repurchase Intention will increase, and vice versa. E-Service Quality is very important in increasing Online Repurchase Intention at Cafes \& Restaurants in Padang City. The effect of satisfaction on Online Repurchase Intention is significant, which explains that the higher the customer satisfaction, the higher the Online Repurchase Intention, and vice versa. 
Customer satisfaction is very important in increasing Online Repurchase Intention at cafes \& restaurants in Padang City. Furthermore, the research results show that satisfaction plays a role as a mediation between E-Service Quality and Online Repurchase Intention. This means, indirectly E-Service Quality affects Online Repurchase Intention, but it needs customer satisfaction first. In other words, E-Service Quality will increase satisfaction, so that satisfied customers will increase Online Repurchase Intention.

\subsection{Limitations}

The limitations of this research can be taken into consideration for future research, namely This study is limited to the effect of E-Service Quality on Online Repurchase Intention with satisfaction as a mediation, The sample in this study was only respondents who had done Online Repurchase Intention at several cafes \& restaurants in Padang City through websites or personal accounts of cafes \& restaurants, such as WhatsApp and Instagram during large-scale social restrictions (PSBB), The object of research was only conducted at local cafes $\&$ restaurants in Padang City, West Sumatra, Indonesia.

\subsection{Suggestions}

The results of this study are expected to help provide input to cafe \& restaurant businesses in the city of Padang in increasing Online Repurchase Intention. The general implication of this research is that there is a delivery unit at local cafes \& restaurants or collaboration with e-commerce so that Online Repurchase Intention develops in local cafes \& restaurants. In particular, the implications of the results of this study are:

a. Online Repurchase Intention at cafes \& restaurants in Padang City can increase if the overall E-Service Quality is satisfactory. Therefore, in order to increase Online Repurchase Intention, E-Service Quality must be improved by improving the dimensions of service quality. For example, the efficiency dimension can be improved through the development of accessible websites and social media. The compensation dimension can be increased through the provision of compensation or guarantees for customer orders that do not arrive, are damaged in transit, take too long to arrive at the destination address. The responsiveness dimension can be increased through fast order processing, handling of complaints and fast delivery of food to customers. The contact dimension can be increased by providing telephone numbers,
WhatsApp, email or interactive chat facilities on the website which are always ready and easily contacted by customers. The fulfilment dimension can be increased by developing a website, Instagram, or other social media that contains complete information about the products and services offered by the company. Meanwhile, the dimension of reliability can be increased by reducing the error rate in sending customer orders and errors in recording customer transaction values. Meanwhile, privacy can be improved by maintaining the confidentiality of information about customer identities and the security of making online payments.

b. Online Repurchase Intention at cafes \& restaurants in Padang city can be increased if overall customers feel satisfaction that exceeds their expectations. Things that need to be considered by cafes \& restaurants in the city of Padang are the appearance of websites and / or social media accounts (WhatsApp / Instagram), which are expected to match the ideal online shop application.

c. There is a delivery service unit that is enforced by local cafes \& restaurants in Padang city in addition to the cooperation carried out with ecommerce for delivery orders.

\section{References}

[1] Abdi, F. (2020). Omzet Kafe di Padang Menurun Terkait Pandemi COVID-19. Retrieved October 7, 2020, from Antara Sumbar website: https://sumbar.antaranews.com/berita/34053 4/omzet-kafe-di-padang-menurun-terkaitpandemi-covid-19

[2] Alwafi, F., \& Magnadi, R. H. (2016). Minat Beli Secara Online Pada Situs Jual Beli Tokopedia.com. Diponegoro Journal of Management, 5(2), 1-15.

[3] Burhanuddin, C. I., \& Abdi, M. N. (2020). Ancaman Krisis Ekonomi Global Dari Dampak Penyebaran Virus Corona (Covid19). Akmen, 17(1), 710-718.

[4] Chou, S. W., \& Hsu, C. S. (2016). Understanding Online Repurchase Intention: Social Exchange Theory And Shopping Habit. Information Systems and E-Business Management, 14(1), 19-45. https://doi.org/10.1007/s10257-015-0272-9

[5] Dharmmesta, B. S. (2014). Manajemen Pemasaran Modern. Liberty.

[6] Hair, J. F., Black, W. C., Babin, B. J., \& Anderson, R. E. (2014). Multivariat Data 
Analysis. Pearson Education Limited.

[7] Hasman, H. C. P., Ginting, P., \& Rini, E. S. (2019). The Influence of E-Service Quality on E-Satisfaction and Its Impact on Repurchase Intention in Using E- Commerce Applications on Students of Universitas Sumatera Utara. International Journal of Research and Review, 6(10), 299-307.

[8] Ibzan, E., Balarabe, F., \& Balarabe, J. (2016). Consumer satisfaction and repurchase intentions. Developing Country Studies, 6(2), 96-100. Retrieved from http://www.iiste.org/Journals/index.php/DCS /article/view/28624

[9] Lestari, V. T., \& Ellyawati, J. (2019). Effect of E-Service quality on repurchase intention: Testing the role of e-satisfaction as mediator variable. International Journal of Innovative Technology and Exploring Engineering, 8(7C2), $158-162$. https://doi.org/10.35940/ijitee.g5400.088101 9

[10] Merdeka. (2020). Daftar Industri yang Terdampak Corona, Paling Besar Sektor Makanan dan Minuman. Retrieved October 7, 2020, from Merdeka website: xhttps://www.merdeka.com/uang/daftarindustri-yang-terdampak-corona-palingbesar-sektor-makanan-dan-minuman.html

[11] Phuong, N. D., \& Tran, N. D. (2018). Repurchase Intention: The Effect of Service Quality, System Quality, Information Quality, and Customer Satisfaction as Mediating Role: A PLS Approach of MCommerce Ride Hailing Service in Vietnam. Marketing and Branding Research, 5(2), 7891. https://doi.org/10.33844/mbr.2018.60463

[12] Rita, P., Oliveira, T., \& Farisa, A. (2019). The Impact Of E-Service Quality And Customer Satisfaction On Customer Behavior In Online Shopping. Heliyon, 5(10), e02690. https://doi.org/10.1016/j.heliyon.2019.e0269 0

[13] Santika, I. W., \& Pramudana, K. A. S. (2018). Peran Mediasi E-Satisfaction Pada Pengaruh
E-Service Quality Terhadap E-Loyalty Situs Online Travel Di Bali. INOBIS: Jurnal Inovasi Bisnis Dan Manajemen Indonesia, 1(3), 278-289.

https://doi.org/10.31842/jurnal-

inobis.v1i3.35

[14] Santoso, A., \& Aprianingsih, A. (2017). The Influence of Perceived Service and E-Service Quality To Repurchase Intention the Mediating Role of Customer Satisfaction Case Study: Go-Ride in Java. Journal of Business and Management, 6(1), 12.

[15] Saodin, Suharyono, Arifin, Z., \& Sunarti. (2019). The Influence of E-Service Quality Toward E-Satisfaction, E-Trust, E-Word of Mouth and Online Repurchase Intention: a Study on the Consumers of the Three-Star Hotels in Lampung. Russian Journal of Agricultural and Socio-Economic Sciences, 93(9), 27-38. https://doi.org/10.18551/rjoas.2019-09.03

[16] Sekaran, U., \& Bougie, R. (2016). Research Methods For Business: A Skill Building Approach. John Wiley \& Sons, Inc.

[17] Silalahi, U. (2018). Metode Penelitian Sosial. Bandung: PT Refika Aditama.

[18] Simanjuntak, H. S. (2020). Usaha Online Untuk Pemula di Masa Pandemi Covid-19. Retrieved October 7, 2020, from Daya website: https://www.daya.id/usaha/artikeldaya/pemasaran/usaha-online-untuk-pemuladi-masa-pandemi-covid-19

[19] Sugiyono. (2017). Metode Penelitian Kuantitatif, Kualitatif dan $R \& D$. Bandung: Alfabeta.

[20] Zeithaml, V. A., Parasuraman, A., \& Malhotra, A. (2002). Service quality delivery through web sites: A critical review of extant knowledge. Journal of the Academy of Marketing Science, 30(4), 362-375. https://doi.org/10.1177/009207002236911 